\title{
$\star$ 酽造物の機能性
}

\section{清酒の健康と美容効果}

\begin{abstract}
食物と健康に関する情報は, 誰もが興味を持つ話題である。酾造物は健康機能を有する食品 として科学的に衰付けされているものが多く，光の一つである酒類でも健康機能を有する成分 が見い出され, アルコールによる弊害よりも，機能性の面から論じられることが多くなってき ている。以後 3 回にわたって清酒に関連する機能性について, 解説していただいた。
\end{abstract}

1. は じめ に

日本酒の美味しい季節になった。最近は燗の良さが 見直されて冷やのお酒と燗のお酒が好みや料理により 決まるようになってきた。

さて, 今から 5 年前, 私の先輩の一人から「今度地 球社から健康のためにはバランスのとれた食生活とい う趣旨で, フードルネサンスというシリーズの本を出 す。私たちの普段の食生活の中で，一生にわたって食 べる身近な食べ物を取り上げるが，私はスパイスをや るから貴方は清酒をやれ」と依頼があり，私は即座に 「やっぱり清酒は百薬の長」でいこうと決心した。

ところが実際に書こうとして, 清酒のヘルシー効 果 ${ }^{1)}$ についての科学的な裏付けがあまりにも少ないの に気付いた。判っていたのは, 癌の抑制関係と, 他に アルコールそのものの効果が知られている位。

引き受けた以上は仕方がないので, 日本酒の歴史や 製造法, 料理, 酒器, 酒道などの情報, 文化について 分担執筆することとし，「脳内革命」 $\rfloor^{2)}$ ではないが，日 本酒で楽しく食事することができれば，脳内に $\beta$-エ ンドルフィンが増加し, 快適さがさらに深まって健康 に寄与すると考えその方針で進んだ。

しかし一方, 当社の総合研究所 (今後月桂冠と略す る。にに指示していた「日本酒の成分のなかに身体に とって悪いものがないか徹底的にやろう」に対して, 研究陣は「悪いものはない。」れどころか次から次
へと良い方の結果を出してきた。他の医学関係からも 日本酒の良さに対する報告が出始め，その本の執筆を 続行することができた。

昨年 9 月に発行したが, 後から聞くと, 心筋梗塞の 予防に関してワインも大体同じ頃からポリフェノール の効果が科学的に裏付けられているので, 必ずしも日 本酒が遅かったわけでもない。

ところで，8月 29 日付の新聞紙上に，日本人の平 均寿命は女性 83.82 歳, 男性 77.19 歳, 男女差 6.63 歳長寿世界一が報じられた。人生 80 年時代の到来と 言える。この男女差も過去最高で, 男性の生物学的な 体質, 契煙習慣, 過飲酒や社会から受けるストレスの 差が原因と指摘されている。社会的責任を男女が平等 に分担する社会の実現が望まれるという人もいる。将 来の死因を予想すると, 男女とも癌で死亡する確率が 同じくトップで, 特に男性 $29.43 \%$ と高率である。女 性は脳血管疾患, 心疾患の順, 男性は心疾患, 脳血管 疾患の順となり,三大死因をあわせると $50 \%$ を越える。 心疾患と脳血管疾患はいづれも動脈硬化が原因で, そ れはコレステロールに由来しており，その黒幕は中性 脂肪と言われている。もし癌が克服されると男性が+ 4.02 歳, 女性が 2.9 歳, 三大死因全てが克服される と男性 +8.88 歳即ち 86.07 歳, 女性 +7.96 歳で 91.78 歳となる。

これらの死因に対して日本酒の適量飲酒が如何に関 わり，健康に良い結果を及ほしているかを取り上げて 
みたい。

食物と健康に関しては, 最近京都大学大学院人間環 境学研究科教授で WHO 循環器疾患予防国際共同研 究センター所長の家森幸男氏が興味深いことを述べて いる。人間は遺伝的に大体その人のかかる病気が決ま つていると従来考えられていたが，世界の 25 ケ国と 60 地域（南は夕ンザニアのマサイ族から北はスウェ ーデン，フィンランドまで）を研究対象として毎日の 食習慣によって遺伝に関わらず高血圧による脳卒中, 心筋梗塞, 糖尿病などの生活習慣病を予防でき, 天寿 を全うできることがだんだん判ってきだ”。しかも， 食習慣によって寝たきりや痴呆ではなく長寿で, 美味 しい物をたべて QOL（生活の質）の高い生活ができ るようになり，高齢化社会の展望は明るい。今や何を 食べれば長寿を楽しめるのかはっきりしてきた。まさ にWHOの標語「Eat Wisely, Live Well」“賢く食 べて元気に生きょう”の時代がやってくる。その WHO の標語ポスターには各種の食材のてっぺんに, 箸を二本立てた山盛りご飯がのっているものが取り上 げられて全世界に配られている。健康には米のご飯が 重要であるということが国際社会に認められてきたの かもしれない。

米のご飯には魚と大豆と海藻のおかずが合い, ご飯 を食べている限り動脈硬化は少ない。また, 魚は心筋 梗塞を防ぎ, 大豆にはタンパク質, 脂肪酸, ミネラル があり, イソフラボンもある。結果, 心臓死, 脳卒中 も少ないのである。その米を原料としているのがまさ に日本酒であり, 日本料理とも最も相性のよい伝統的 食品ということになる。

業界の新聞に,「ワインが健康で成功したからとい って清酒まで体によいなんて PRするのは愚の骨頂。 益々ワインの後塵を拝することになる。需要開発に努 力すべきことはまだまだある。」と書いてあった。

ワインは健康だけで成功したのではない。しかし， 清酒の健康に対する誤解があまりにも多すぎる。これ を是正しなければ基本で遅れをとる。メルシャンの鈴 木社長は,「追い風となったのは事実だが, 仕掛けた のだ。今やPOS も限界で, 市場顧客に働きかけ仕掛 けるしかない。 4 年半ほど前から, 市場の情報によっ てなぜワインが売れないかを解析した結果, 女性がワ インを最も飲みたいと思っていることや割高感を持っ ていることを知り，また通がもっともらしく知識をひ
けらかすことから手を出しにくいイメージがあった。 そこで $720 \mathrm{~m} \ell 500$ 円以下のワインを販売し, これに は南アメリカのワインなど新世界のワインを入れたり， ブドウ果汁を移入して発酵させたりして，この低価格 を達成した。コルク栓の代わりにネジ栓とし, 開栓後 冷蔵庫に入れておけば一週間は十分もつと明示し た。と言われている。

そうした上にまず海外で発表されたが，日本でも国 立健康栄養研究所なども夕イミングよく「ワインが心 臟疾患によい」ということでブームになった。

しかし，フレンチパラドックスと言われるが，一番 のワイン消費国のイタリアやスペインではどうか。何 と言っても我が国が世界一の長寿国であり, ジャパニ ーズパラドックスとも言われていることを思えば, 後 で触れるような科学的, 医学的な根拠によって日本酒 のヘルシーさも世界一ではないかという結論になりそ うである。

鑑定企画官により「清酒の品質について」の提言が 今回出されたので, それも併せて日本酒の不買動機を 検討すると, 第一の割高感については, 日本の米の価 格は世界の米と比較して約 6 倍ぐらいで，たとえ輸入 しても輸入米に対するSBS など, ワインなどと比較 して明らかに不利となる。

また, 日本酒のイメージについても, 例えばイメー ジの中には「高級な」とか「ロマンティックな」とい ろいろあるが, アンケートではワインに劣る。また， 今迄の健康イメージも一つのマイナス部分と言える。 日本酒は糖尿病に悪いというのが医者仲間の通説で あった。糖尿病というのは生活習慣病で, 糖尿病に悪 いと言われてイメージはどうなるのか。ところが，日 本酒の中にその糖尿病に良い効果を示すと考えられる インシュリン様物質が存在することを, 糖尿病の権威 である愛媛大学の奥田教授が発見した。

このように, 日本酒の言われのない誤解を解くのは 愚の骨頂でも何でもなく，正しいことは早急に発信し てまちがいを直さなければならない。

私共は, 日本酒にヘルシー効果があっても薬の代わ りなどとは毛頭考えていない。少なくとも 15 項目に ついて, 特に生活習慣病についてプラス効果があるこ とさえ知ってもらえれば嬉しい。楽しく美味しく日本 酒を適量飲酒することは健康に良いということを科学 的な裏付けをもって証明してみたい。これらの効用の 
大部分が黄麴菌と米とによる事が判ってくると, 世界 でこれらの原料と菌を多く使っている日本酒が日本の 長寿世界一に何らかの貢献をしていることは当然のこ とと思える。

私共の業界は, 2000 年に及ぶ先達の努力による伝 統や優秀さなどがあっても，あまりにも身近で当たり 前のようになうているので PRしていないが，これか らの時代もっともっと発言してもよいのではないかと 思われる。まずはとりあえずヘルシー効果の真実を知 って欲しい。

\section{2. 適量飲酒}

（病気にならない飲み方）

適量飲酒というのは病気にならない飲み方であり, 適正飲酒というのはセンシシブルドリンキング, 節度 のある飲み方という意味である。

1）マーモット U 字型死亡率曲線4

この死亡率曲線から飲酒には適量があることが判る。

さらに 1993 年 R・カーライス・エリソン博士によ って J カーブが確認され, 適量飲酒は全死亡率を低下 させ健康にプラスとなる事が判った。適量には個人差 があり，年齢・体重によっても異なる。肝臟病の場合 は飲酒量に対して直線的に増加するということを頭に 入れておく必要がある。

2）適量飲酒ガイドライン $30 \sim 60 \mathrm{~g}$ （アルコール）

日本酒換算 $1 \sim 2$ 合

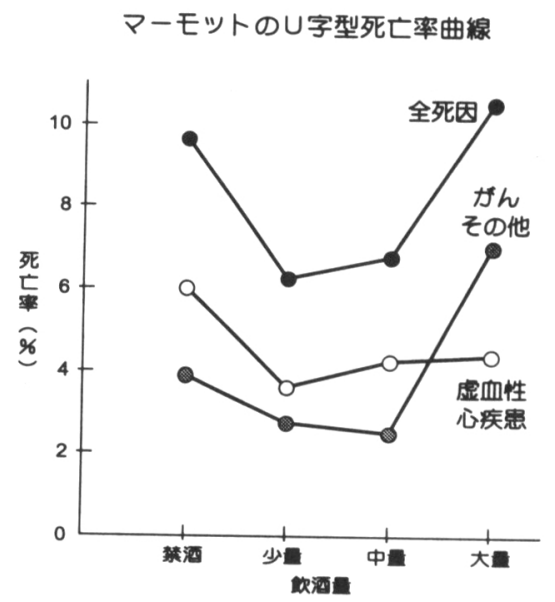

\section{3. 各自の飲酒能力を知る}

1) 呼気法 ${ }^{5)}$

2) 4 つのタイプ $(\mathrm{AA}, \mathrm{AB}, \mathrm{BA}, \mathrm{BB})$

3）酔っぱらい度，二日酔度チェックシート

\section{鱽酒テストの方法}

使用機器: Alcomed 3010 (Envittec社 ドイツ製) モニター：26名（10分間て流酒180m|以上確実に飲める人）

清酒180m|を10分間で飲む<smiles>C[Te]</smiles>

うがいをし、ロ中のアルコールを除去<smiles>[Te][Te]</smiles>

飲酒経了後、10分後か5

呼気中アルコール壊度を測定

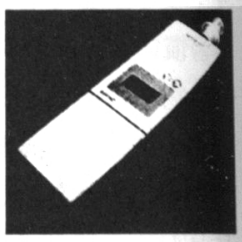

呼気中アルコール貺定器

呼気中にアルコールガ模出されなくなるまて、

10 20分每浮氛測定

\section{飲酒後の呼気中アルコール壊度の变化}

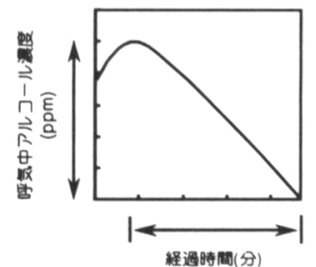

A A

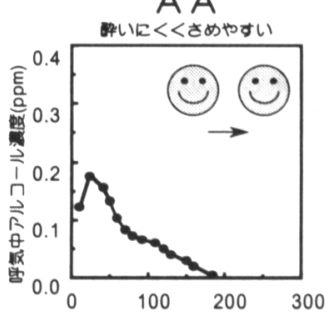

B A

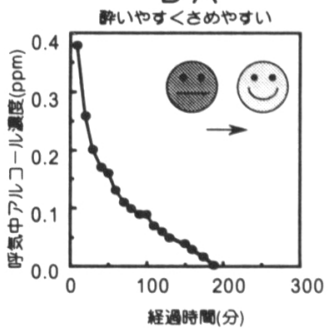

$A B$

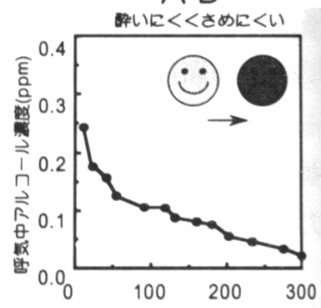

B B

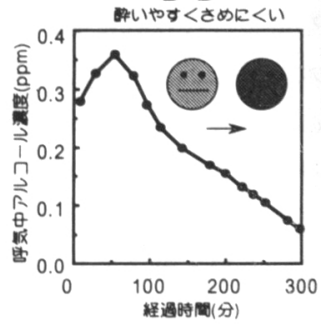

醇協 (1999) 
酔っぱらい度とニ日酔い度のチェックシート

A 醉っぱらい度チェック

（酪いやすいか? )

わ酒を既むと…

(1)目年回ったり、めまいがすることがある

(2)なんとなく悲しくなったり不安になることがある

(3トリ肌だたたり身員いすることがある

(4)息苦しく感じることガある

(5)少量ても叶を気を感じることガある

B 云日醉い度チェック

お酒を飭むと・.

(1)䫓ガ需くなりやすい

(2)身体中がかゆくなることガある

(3)身体ガだるくなることガある

(4)頍が就くなることガある

(5)ドキドキすることガある
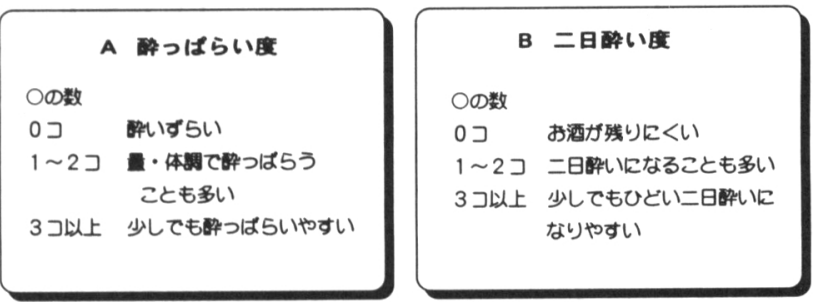

日本テレビ「午後は○○おもいッきりテレビ」より

生体内でのアルコールの吸収

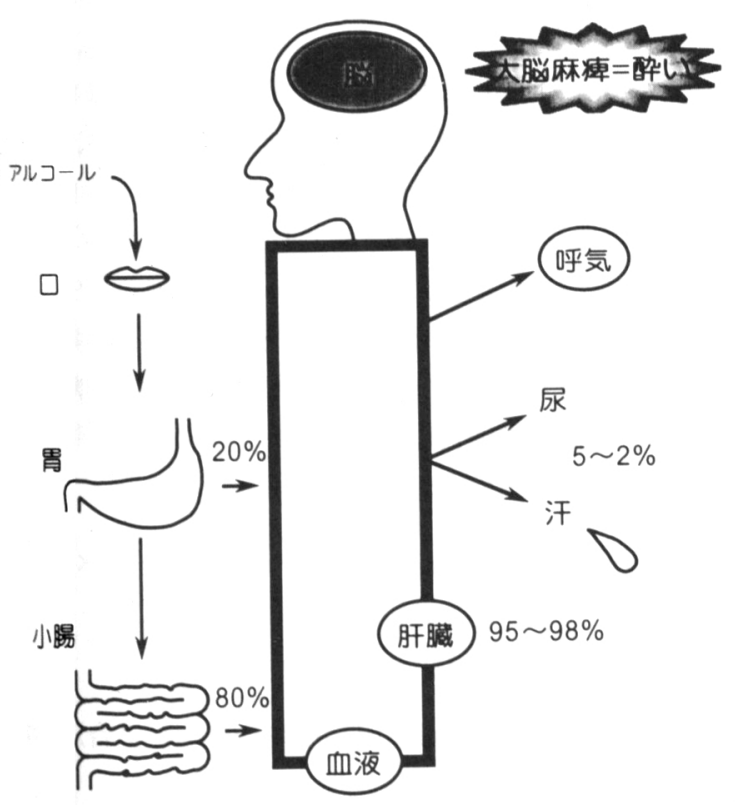

日本人は ALDH 活性型約 $50 \%$ ，不活性へテロは $40 \%$ ，不活性ホモ（全くの下戸）は約 10\%で，白人 はすべて活性型である。

\section{4. 何故酔うのか（酔いのメカニズム）}

飲んだ清酒中のアルコールは, 食道を通って胃, 小 腸で吸収され，血管に入る。胃で約 $20 \%$ ，腸で約 $80 \%$ が吸収され, 門脈を通って肝臓へ行き, 酸化, 分 解される。アルコールの酸化は，アセトアルデヒドを 経由して水と炭酸ガスに代謝される。一部は肝臟で酸 化を受けずに血管によって脳に行く。その後肝臓へ戻 り酸化，分解される。

肝臓でのアルコールは三段階を経て体外へ排出され る。

第一段階はアルコールがアセトアルデヒドになる反 応である。アルコール脱水酵素過酸化水素生産系で分 解を受ける。 
第二段階は，第一段階で生成したアセトアルデヒド が酢酸に酸化される反応である。これはアルデヒド脱 水素酵素が関与する。この酵素が遺伝的に少ないのが 我が国の弥生人体質なのである。

第三段階は, 酢酸が水と炭酸ガスに分解し, 対外に 排出される最後の反応系である。

このように，アルコールは体内で種々の分解を受け 体外に排出されるが，飲み過ぎによる二日酔いの原因 は定かではない。

二日酔いは, 飲酒後 8 14 時間前後に頭痛, 悪心, 嘔吐, 過呼吸, 発汗, または血圧降下などの症状を伴 う不愉快な自覚症状を持つ悪い状態を言う。悪酔いも 二日酔いも，血中アルデヒドがその直接の原因である と言われてきたが, 最近, 京都府立医大の栗山教授ら の研究で血中カテコールアミンがその原因の一つと推 測しているのは非常に興味深いことである。

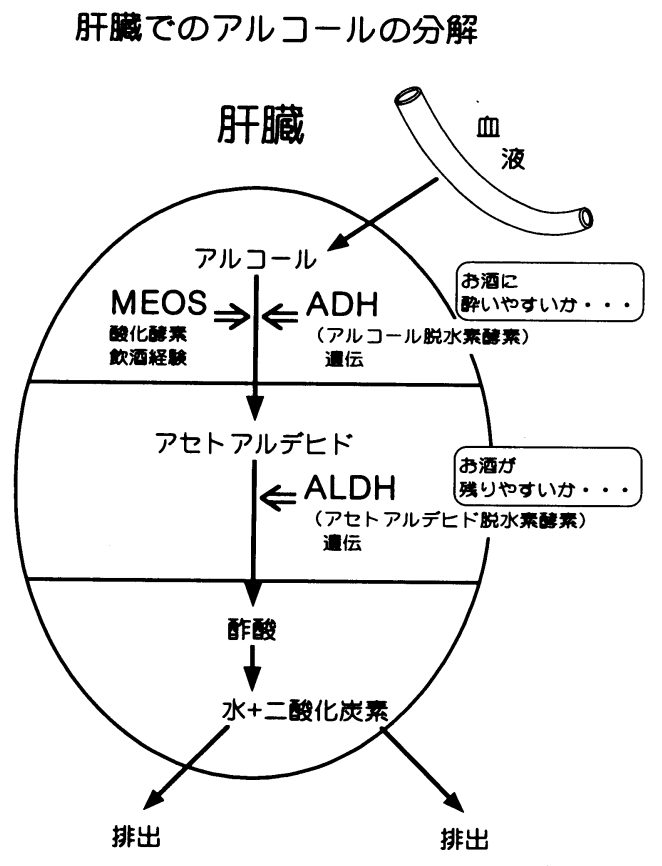

吸収されたアルコールは, 肝臓で 95〜 98\%が代謝 され, 残りの $2 \sim 5 \%$ が尿, 汗, 呼吸などで排泄される。 一部のアルコールの大脳麻痺作用と, 中間代謝物のア セトアルデヒドの毒性による身体症状が酒酔いと考え られる。
通常，酒を飲むと気分が高揚し元気になる。アルコ ールによって初めに麻痺するのは大脳の新皮質にある 抑制機能である。新皮質は大脳の最も外側にある厚さ $2.5 \mathrm{~mm}$ の層で, 創造性や理性といった抑制作用の中 で最も高度な部分を受け持つ部分である。この抑制作 用が低下すると，食欲とか性欲，笑ったり怒ったり这 いたりといった本能的な働きをする大脳辺縁系（大脳 旧皮質）の働きが開放されるので, 活発になり元気が 出たように見えるのである。

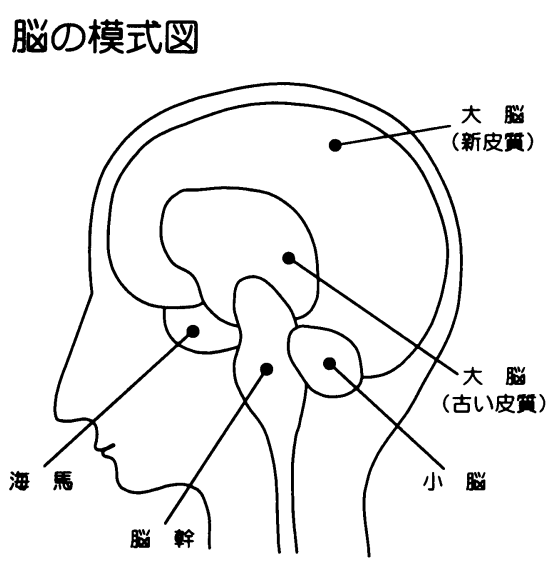

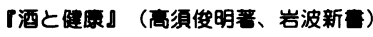

小脳は, 平衡感覚や筋肉の緊張, さらに筋肉同士の 協同運動をコントロールする。海馬は短期記憶, すな わち今したことや見たことなどを一時的に記録してお く場所で, 延髄は最も基本的な生命活動を司り, 心臓 や肝臟機能の内臓諸機関の働きをコントロールしてい る。

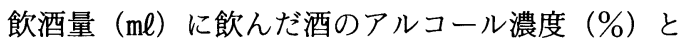
アルコールの比重 0.8 をかけるとアルコールの重量と なる。それを身体の水分（体重の 3 分の 2) で割ると およその血中濃度になる。

アルコール最高血中濃度 $(\%)=$

$\left[30\right.$ 分間の飲酒量 $\left.(\mathrm{m} \ell) \times \frac{\text { アルコール濃度 }(\%)}{100} \times 0.8\right]$

$$
\div\left[\text { 体重 }(\mathrm{kg}) \times 1000 \times \frac{2}{3} \div 100\right]
$$

例えば, 体重 $69 \mathrm{~kg}$ の人が清酒 $360 \mathrm{~m} \boldsymbol{\ell}$ （2 合）を飲 んだとすると，アルコール度 15\%の場合， 
血中アルコール湌度（BAC）と臨床症状

\begin{tabular}{|c|c|c|c|}
\hline$B A C$ & 分 & 路床 症 状 & 酒 \\
\hline $\begin{array}{l}0.02 \\
\sim 0.04 \%\end{array}$ & 器快期 & $\begin{array}{l}\text { 気分さわやカ。 } \\
\text { 活発な的度をとる。 }\end{array}$ & $\begin{array}{l}\text { 日本酒 }(180 \mathrm{ml}) \\
\text { ビール大鲑 ( 1 1本) } \\
\text { ウイスキー (シンテル〜2杯) }\end{array}$ \\
\hline $\begin{array}{l}0.05 \\
\sim 0.1 \%\end{array}$ & $\begin{array}{l}\text { ほろ杂い } \\
\text { 初期 }\end{array}$ & $\begin{array}{l}\text { ほろ卆い気分。眽拍数、呼吸がはやくなる。 } \\
\text { 話はなめらかになり、抑制ガとれる。 }\end{array}$ & $\begin{array}{l}\text { 日本酒 }(180 \mathrm{ml} \sim 270 \mathrm{ml}) \\
\text { ビール大坦 (1〜2本) } \\
\text { ウイスキー (シンワル2〜5杯) }\end{array}$ \\
\hline $\begin{array}{l}0.11 \\
\sim 0.15 \%\end{array}$ & $\begin{array}{l}\text { ほろ杂い亚期 } \\
\text { （680丁前期） }\end{array}$ & $\begin{array}{l}\text { 気が大きくなり、自己抑制がとれる。 } \\
\text { 立てば少しふらつく。 }\end{array}$ & $\begin{array}{l}\text { 日本酒 }(360 \mathrm{ml} \sim 540 \mathrm{ml}) \\
\text { ビール大䭪 (2〜3本) } \\
\text { ウイスキー (シンテル6 8杯) }\end{array}$ \\
\hline $\begin{array}{l}0.16 \\
\sim 0.30 \%\end{array}$ & 百距極期 & 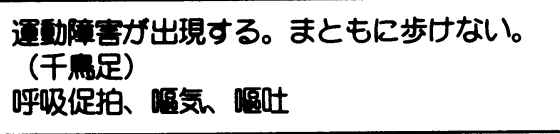 & $\begin{array}{l}\text { 日本酒 }(900 \mathrm{ml} \sim 1200 \mathrm{ml}) \\
\text { ビール大嚗（5〜7本） } \\
\text { ウイスキー（シングル8〜10杯） }\end{array}$ \\
\hline $\begin{array}{l}0.31 \\
\sim 0.40 \%\end{array}$ & 泥动期 & 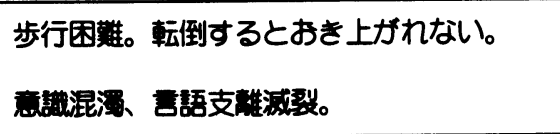 & $\begin{array}{l}\text { 日本酒 }(1260 \mathrm{ml} \sim 1440 \mathrm{ml}) \\
\text { ビール大堙 }(8 \sim 10 \text { 本 }) \\
\text { ウイスキー (ポトル1本 })\end{array}$ \\
\hline $\begin{array}{l}0.41 \\
\sim 0.50 \%\end{array}$ & 奋睡期 & 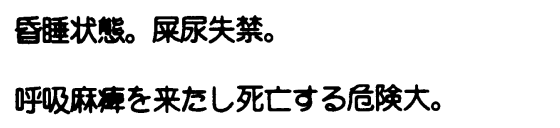 & $\begin{array}{l}\text { 日本酒（1800ml以上） } \\
\text { ビール大境（10本以上） } \\
\text { ウイスキー（ボトル1本以上） }\end{array}$ \\
\hline
\end{tabular}

血中濃度 $(\%)=360 \times \frac{15}{100} \times 0.8 \div 69 \times 1000 \times \frac{2}{3}$

$$
\fallingdotseq 0.09(\%)
$$

となる。

「ほろ酔い」とは血中濃度が $0.1 \%$ 以内にある状態 である。

30 分間に $360 \mathrm{~m} \ell$ （2 合）の酒を飲むとほろ酔い状態 になる人の場合, アルコールは 1 時間に $7 \mathrm{~g}$ （清酒換 算 $60 \mathrm{~m} \ell=$ 約 3 勺）の割合で分解されるため, 1 時間 に 2 合のピッチであればほろ酔いが持続することにな る。

ちなみに我が国の道路交通法の酒気帯び運転の基準 值は血中濃度 $0.05 \%$ 以上である。

日本酒のヘルシー効果の各論については次号に譲る。 (月桂冠(株))
参考 文 献

1）今安 聰 編著：「秘められた清酒のヘルシー 効果」地球社, 東京 (1997)

2）春山茂雄：「脳内革命」サンマーク出版, 東京 (1995)

3）家森幸男:「不老長寿の科学」, 第 3 章 世界の 長寿村, pp. 39〜61 (1993)

4) M. G. Marmot, G. Rose, M. J. Shipley and B. J. Thomas: Lancet, 14, 580 583 (1981)

5）武田奈帆子, 白潟昌彦, 秦洋二, 市川英治, 川 戸章嗣，杉並孝二：醸協，92，677（1997） 